\title{
The effect of weight reduction on skeletal muscle UCP2 and UCP3 mRNA expression and UCP3 protein content in Type II diabetic subjects
}

\author{
P. Schrauwen ${ }^{1}$, G. Schaart ${ }^{2}$, W.H.M.Saris ${ }^{1}$, L.J.Slieker ${ }^{4}$, J.F.C. Glatz ${ }^{3}$, H. Vidal ${ }^{5}$, E. E. Blaak ${ }^{1}$ \\ ${ }^{1}$ Department of Human Biology, Maastricht University, Maastricht, The Netherlands \\ ${ }^{2}$ Department of Movement Sciences, Maastricht University, Maastricht, The Netherlands \\ ${ }^{3}$ Department of Physiology, Maastricht University, Maastricht, The Netherlands \\ ${ }^{4}$ Eli Lilly and Company, Lilly Corporate Center, Indianapolis, Indiana, USA \\ ${ }^{5}$ Inserm Unit 449, Faculty of Medicine René Laennec, Lyons, France
}

\section{Abstract}

Aims/hypothesis. The aim of this study was to examine the effect of weight loss on UCP2/UCP3 mRNA expression and UCP3 protein content in subjects with Type II (non-insulin-dependent) diabetes mellitus.

Methods. We studied seven Type II diabetic subjects who followed a 10 -week very low calorie diet. Expression of skeletal muscle UCP2 and UCP3 mRNA was measured using RT-competitive PCR and UCP3 protein content by western blotting, before and after the diet. Total and plasma fatty acid oxidation was measured using infusion of ${ }^{13} \mathrm{C}$ labelled palmitate.

Results. Body weight decreased from $105.5 \pm 8.2 \mathrm{~kg}$ to $91.6 \pm 7.2 \mathrm{~kg}(p<0.001)$, after 10 weeks of diet intervention. Expression of UCP2 and UCP3 mRNA were significantly reduced after 10 weeks of diet $(p<0.05)$ but UCP3 protein contents were not significantly altered. Notably, the change in UCP3L mRNA expression and UCP3 protein content after the very low calorie diet were negatively associated with changes in body weight $(r=-0.97, p=0.006$ and $r=-0.83, p=0.043$, respectively) and $\mathrm{BMI}$ $(r=-0.99, p=0.0007$ and $r=-0.9, p=0.016$, respectively). Furthermore, changes in UCP3L mRNA expression and UCP3 protein content induced by the diet were positively correlated with changes in cytosolic fatty acid-binding protein content $(r=0.93$, $p=0.023$ and $r=0.84, p=0.039$, respectively). No correlation between diet-induced changes in UCP3 protein and resting energy expenditure or plasma non-esterified fatty acid concentrations were found.

Conclusion/interpretation. The negative correlation between the change in UCP3 protein content after weight loss and the change in BMI, suggests that the decrease in UCP3 during weight loss could prevent further weight loss. The finding that the change in UCP3 protein content correlates with the change in skeletal muscle fatty acid-binding protein content, suggests a role for UCPs in the handling of lipids as a fuel. [Diabetologia (2000) 43: 1408-1416]

Keywords UCP2, UCP3, western blotting, obesity, gene expression, Type II diabetes, very low calorie $\operatorname{diet}(\mathrm{VLCD})$.
The uncoupling proteins 2 and 3 (UCP2 and UCP3) are probable candidates for underlieing the variability in human energy metabolism. The uncoupling pro-

\section{Received: 7 June 2000 and in final revised form: 21 July 2000}

Corresponding author: Dr. P. Schrauwen, Department of Human Biology, Maastricht University, P.O. Box 616, 6200 MD Maastricht, The Netherlands

Abbreviations: FABP, Fatty acid-binding protein; FFM, free fat mass; TCA, tricarboxylic acid; UCP, uncoupling protein; VLCD, very low calorie diet. tein genes encode for mitochondrial protein carriers, which uncouple mitochondrial respiration from ATP production and thus stimulates heat production [1]. The UCP2 is ubiquitously expressed in different tissues, whereas UCP3 is mainly expressed in skeletal muscle $[2,3]$. Furthermore, UCP3 is expressed in a long (UCP3L) and a short (UCP3S) isoform, the latter lacking part of exon 6 and exon 7, probably resulting in a truncated protein. Genetic studies have indicated that polymorphisms in the UCP2 or $U C P 3$ gene or both are associated with altered metabolic rate $[4,5]$. Recently, we showed that the expression 
Table 1. Subjects' characteristics

\begin{tabular}{lcc}
\hline Variable & before & after \\
\hline Age (years) & $51 \pm 3$ & - \\
Weight $(\mathrm{kg})$ & $105.5 \pm 8.2$ & $91.6 \pm 7.2^{\mathrm{a}}$ \\
Height $(\mathrm{m})$ & $1.78 \pm 0.04$ & - \\
BMI $\left(\mathrm{kg} / \mathrm{m}^{2}\right)$ & $32.9 \pm 1.3$ & $28.6 \pm 1.3^{\mathrm{a}}$ \\
$\%$ body fat & $35.9 \pm 1.2$ & $29.0 \pm 2.1^{\mathrm{a}}$ \\
$\mathrm{VO} 2_{\max }\left(\mathrm{ml} \cdot \mathrm{min}^{-1} \cdot \mathrm{kg} \mathrm{FFM}^{-1}\right)$ & $38.3 \pm 2.8$ & $42.1 \pm 2.4$ \\
glucose $(\mathrm{mmol} / \mathrm{l})$ & $8.4 \pm 0.6$ & $7.8 \pm 0.8$ \\
NEFA $(\mu \mathrm{mol} / \mathrm{l})$ & $739 \pm 95$ & $502 \pm 115^{\mathrm{a}}$ \\
\hline
\end{tabular}

${ }^{\mathrm{a}} p<0.05$ compared with before

Values are expressed as means \pm SEM

of UCP3 mRNA positively correlates with sleeping metabolic rate in Pima Indians, suggesting that UCP3 is a determinant of human energy metabolism [6]. Furthermore, a positive correlation between UCP2 mRNA expression in adipose tissue and resting metabolic rate has been shown previously [7]. These results therefore provide evidence for a role of the new UCPs in human energy metabolism.

In addition to a role for UCPs in human energy metabolism, suggestions have been made that UCPs are also involved in the metabolism of fatty acids. Fasting up-regulates the expression of UCP2 $[8,9]$ and UCP3 $[10,11]$ mRNA in rodents and in humans [12]. The effect of fasting on the expression of UCPs could be attributed to increased circulating concentration of NEFA because a positive correlation between plasma NEFA concentrations and UCP3 mRNA expression has been shown [13]. Also, increased concentrations of plasma NEFA, by infusing of a triglyceride emulsion, have been shown to up-regulate UCP3 mRNA expression in rats [14] and in humans [15]. In the conditions described above (fasting, increased NEFA) fat oxidation is, however, also increased and it has been suggested that UCPs could act as transporters of fatty acids across the mitochondrial membrane, thus having a role in the handling of lipid as a fuel $[9,16]$.

Type II (non-insulin-dependent) diabetes mellitus is characterized by alterations in lipid metabolism. For example, it has been shown that Type II diabetic subjects have an increased plasma NEFA concentration and decreased uptake of plasma NEFA by the skeletal muscle $[17,18]$. Notably, it has recently been shown that Type II diabetic subjects, in contrast to obese and lean subjects, were unable to up-regulate $\mathrm{UCP} 2$ and UCP 3 mRNA expression in response to a 5-day fasting period [19]. Weight reduction has also been shown to influence UCP expression in humans. In non-diabetic obese subjects, weight reduction decreased UCP2 and UCP3 mRNA expression [20, 21]. A reduced UCP3 mRNA expression after weight loss could contribute to the decreased energy expenditure or lowered fat oxidation or both observed after weight loss, probably leading to a rapid regain in body weight. The question remains, however, whether changes in UCP3 mRNA are translated to changes in UCP3 protein. Therefore, the aim of our study was to examine whether Type II diabetic subjects are capable of reducing UCP2 and UCP3 mRNA expression and UCP3 protein after weight reduction and whether this decrease is related to changes in energy metabolism or fatty acid transport/oxidation or both.

\section{Subjects and methods}

Subjects. We studied seven male obese Type II diabetic subjects. Due to technical reasons, however, from one out of seven subjects no UCP3 protein and from two out of seven subjects no RNA could be measured. Subjects' characteristics are given in Table 1. None of the subjects had serious health problems apart from their diabetes. There were four subjects who were using oral blood glucose lowering medication (sulphonylureas). Medication was withheld at least 2 days before the start of the experiments and during the entire diet period. A normal resting ECG, blood pressure and blood lipid-profile were prerequisites for participation in the study. None of the subjects did sport more than 3 hours a week or had a physically demanding job. The study protocol was approved by the medical ethics review committee of the Maastricht University and all subjects gave written informed consent.

Experimental design. At baseline, body composition and maximum aerobic power were measured in all subjects. On a separate day, a muscle biopsy specimen was taken after an overnight fast. In the diabetic subjects, plasma fatty acid oxidation was measured in every subject, using a ${ }^{13} \mathrm{C}$-palmitate infusion test. For this, the subjects participated in two stable isotope experiments, separated by 2 weeks. In these tests an infusion of either $\left[\mathrm{U}_{-}{ }^{13} \mathrm{C}\right]$-palmitate infusion or $\left[1,2-{ }^{13} \mathrm{C}\right]$-acetate infusion was given for 2 hours at rest. Acetate is directly converted to acetyl-CoA and the recovery of acetate can be used to correct ${ }^{13} \mathrm{C}$-palmitate oxidation for loss of label in the tricarboxylic acid (TCA) cycle, as described previously [22, 23]. All these measurements were repeated after the 10 -week diet intervention.

Diet. The diet consisted of a liquid high-protein very low calorie diet (VLCD, $52 \mathrm{~g}$ protein, $50 \mathrm{~g}$ carbohydrates, $7 \mathrm{~g}$ fat and $1.3 \mathrm{~g}$ sodium a day and a micro nutrient intake which meets the Dutch recommended daily allowances), in the form of sachets of soluble powder (Modifast, Novartis Nutrition, The Netherlands). Subjects had to replace all meals by the sachets, which provided $2000 \mathrm{~kJ} /$ day. After 4 weeks, the subjects were allowed to replace one sachet a day with an energy restricted meal (dinner), which was increased to two energy restricted meals/day in week 6 . In weeks 7 and 8 subjects ate an energyrestricted meal three times daily, resulting in an energy intake of about $4200 \mathrm{~kJ} / \mathrm{day}$. The last 2 weeks, subjects returned to stable weight conditions. During the whole dietary period, the subjects were advised and guided to adjust their eating pattern according to the Dutch guidelines for healthy nutrition (30-35 energy $\%$ as fat).

Isotope infusion test. In the morning at 0800 hours, subjects underwent an isotope infusion test, as described previously [24]. Thus, teflon catheters were inserted in an antecubital vein for isotope infusion and retrogradely into a contralateral dorsal hand vein for sampling of arterialized venous blood. After 
placement of the catheters subjects rested on a bed and the cannulated hand was placed in a hot-box where air was circulated at $60^{\circ} \mathrm{C}$ to obtain arterialized venous blood. After $30 \mathrm{~min}$, baseline oxygen consumption and carbon dioxide production were measured and breath and blood samples were collected. Immediately thereafter, subjects were given an intravenous dose of $0.085 \mathrm{mg} / \mathrm{kg}$ of $\mathrm{NaH}^{13} \mathrm{CO}_{3}$ to prime the bicarbonate pool. Then, at $\mathrm{t}=0$, a constant intravenous infusion of either $\left[\mathrm{U}^{1}{ }^{13} \mathrm{C}\right]$-palmitate $\left(0.00806 \mu \mathrm{mol} \cdot \mathrm{min}^{-1} \cdot \mathrm{kg}^{-1}\right)$ or $\left[1,2-{ }^{13} \mathrm{C}\right]$-acetate $\left(0.0645 \mu \mathrm{mol} \cdot \mathrm{min}^{-1} \cdot \mathrm{kg}^{-1}\right)$ was started and continued for $120 \mathrm{~min}$. With these infusion rates, the amount of ${ }^{13} \mathrm{C}$ infused during palmitate and acetate infusion are similar. The concentration of palmitate in the infusate was measured for each experiment, to measure the exact infusion rate, on an analytical gas chromatography using heptadecanoic acid as internal standard (see sample analysis). The palmitate tracer $\left(60 \mathrm{mg}\right.$ of potassium salt of $\left[\mathrm{U}^{-13} \mathrm{C}\right]$-palmitate, $99 \%$ enriched, Cambridge Isotope Laboratories, Andover, Mass., USA) was dissolved in heated sterile water and passed through a $0.2-\mu \mathrm{m}$ filter into a $5 \%$ warm human serum albumin to make a $0.670 \mathrm{mmol} / \mathrm{l}$ palmitate solution. The acetate concentration was measured in each infusate with an enzymatic method (Boehringer, Mannheim, Germany). The acetate tracer (sodium salt of $\left[1,2-{ }^{13} \mathrm{C}\right]$-acetate, $99 \%$ enriched, Cambridge Isotope Laboratories) was dissolved in $0.9 \%$ saline. The chemical and isotopic purity ( $99 \%$ ) of palmitate and acetate tracers were checked by ${ }^{1} \mathrm{H}$ and ${ }^{13} \mathrm{C}$ nuclear magnetic resonance (NMR) and GC/MS. Blood samples and breath samples were taken at $\mathrm{t}=0,90,100,110$ and $120 \mathrm{~min}$. We measured $\mathrm{VO}_{2}$ and $\mathrm{VCO}_{2}$ continuously during the first 90 min using open circuit spirometry Oxycon- $\beta$ (Mijnhardt, Bunnik, The Netherlands).

Muscle biopsy, RNA and UCP3 protein measurement. Muscle biopsy specimens were taken from the mid-thigh region from $\mathrm{m}$. vastus lateralis according to a previously described technique [25]. The subjects were required to abstain from training or vigorous exercise $24 \mathrm{~h}$ before the biopsy. Part of the biopsy specimen was used for isolation of total RNA using an acid phenol method described previously [26], with an additional DNase digestion step with concomitant acid Phenol extraction and ethanol precipitation. Human UCP2 and UCP3 mRNAs were quantified by RT-competitive PCR [12, 27]. Human UCP2 mRNA expression was measured using a specific competitor DNA obtained by the deletion of 55 bp from a 290-nt long UCP2 cDNA fragment, as described previously [12]. Quantitative RT-PCR was done with 5'-GACCTATGACCTCATCAAGG-3' as sense primer and 5'-ATAGGTGACGAACATCACCACG-3' as antisense primer. The UCP3L (390 nt long) and UCP3S (436 nt long) cDNA fragments were obtained by RT-PCR on human skeletal muscle total RNA using $\mathrm{UCP}_{\mathrm{T}} \mathrm{S}$ (5'-ATGGACGCCTACAGAACCAT-3') as sense primer and $\mathrm{UCP}_{\mathrm{L}} \mathrm{S}$ (5'-TACGAACATCACCACGTTCC-3') or $\mathrm{UCP}_{3} \mathrm{AS}$ (5'-TCACCGCTACATCCCAGGTT-3'), respectively as antisense primers. The two competitor DNAs were obtained by a deletion of $40 \mathrm{bp}$ [27]. For the assay, the reverse transcription reaction was done from $0.1 \mu \mathrm{g}$ of skeletal muscle total RNA in the presence of a thermostable reverse transcriptase (Tth, Promega, Madison, Wis., USA) by use of one of the specific antisense primers. The competitive PCR assays were done as described previously $[12,27]$. To improve the quantification of the amplified products, fluorescent dye-labelled sense oligonucleotides were used. The PCR products were separated and analysed on an alf express DNA sequencer with the Fragment Manager Software (Pharmacia biotech, Roosendaal, The Netherlands). Total RNA preparations and RT-competitive PCR assays of the two skeletal muscle samples from the same subject (before and after weight loss) were done simultaneously.

The remaining part of the muscle biopsy specimens were homogenized in ice-cold TRIS-EDTA buffer at $\mathrm{pH}$ 7.4. The homogenates were subsequently sonicated for $4 \times 15 \mathrm{~s}$ and centrifuged at $10000 \times g$ for $2 \mathrm{~min}$ at $4{ }^{\circ} \mathrm{C}$ to remove cell debris. After sonication and centrifugation, two volumes of each skeletal muscle homogenate and one volume SDS-sample buffer $(2 \times)$ were boiled for $4 \mathrm{~min}$ [28]. All samples contain equal amounts of protein (60 ng protein per lane) and were loaded simultaneous on a $13 \%$ polyacrylamide gel containing $0.1 \%$ SDS and electrophoresis was done using a Mini-Protean 3 Electrophoresis Cell (Bio-Rad Laboratories, Hercules, Calif., USA) followed by western blotting using a Mini Trans-Blot Electrophoretic Transfer Cell (Bio-Rad Laboratories, Hercules, Calif., USA). The separated polypeptides were transferred to a nitrocellulose membrane $(0.45 \mu \mathrm{m}$, Bio-Rad Laboratories $)$ by blotting [29] for $1 \mathrm{~h}$ at $100 \mathrm{~V}$ in a cold $\left(4^{\circ} \mathrm{C}\right)$ buffer containing $25 \mathrm{mmol} / \mathrm{l}$ TRIS, $192 \mathrm{mmol} / \mathrm{l}$ glycine and $20 \%$ methanol.

For detection of UCP3 an affinity purified rabbit polyclonal antibody (code:1331, kindly provided by L. J. Slieker, Eli Lilly and Company) prepared against a 20 aa-peptide (human sequence aa 147-166), which recognizes the long and the short form of UCP3 and did not recognise UCP2. The antiserum was affinity purified on a Sulfolink column (Pierce, Rockford, Ill., USA) containing the peptide coupled through a C-terminal Cys. Upon affinity chromatography the purified serum was tested for specificity using recombinant hUCP2 and hUCP3 and rat mitochondria that were treated with triiodothyroine (T3). Other antiserum specificity checks that were done were incubation with the non-immune serum and pre-incubation of the antibody with the peptide. Cross-reaction of the antibody with other proteins was checked for by examining the entire 94000-95000 $\mathrm{M}_{\mathrm{r}}$ range for additional bands. The molecular weight of the band visualised by chemiluminescence was compared with reference values.

After protein transfer, nitrocellulose sheet containing all samples was blocked with $5 \%$ non-fat dry milk in $0.05 \%$ Tween-20/PBS and subsequently incubated with the UCP-3 antiserum (diluted 1:1000 in 5\% non-fat dry milk in $0.05 \%$ Tween 20/PBS) while being shaken gently overnight at room temperature. Thereafter the blot was incubated for $60 \mathrm{~min}$ with horseradish peroxidase conjugated swine anti-rabbit Ig (Dako, Glostrup, Denmark) at a dilution of 1:10000. The blot, containing all muscle samples, was washed for $2 \mathrm{~h}$ in $0.05 \%$ Tween 20/PBS and treated for 1 min with chemiluminescence substrate according to a standardized method (Super Signal West Dura Extended Duration Substrate; Pierce, Rockford, Ill., USA). Finally, a clear blue x-ray film (CL-Xposure Film; Pierce) was exposed to the nitrocellulose sheet for $1 \mathrm{~min}$. The reaction product of each sample was analysed by densitometry using Imagemaster (Pharmacia biotech) and protein content is expressed as optical density per $60 \mathrm{ng}$ of protein.

Tissue content of heart-type or muscle-type cytoplasmatic fatty acid-binding protein (FABP) in skeletal muscle was measured by means of a newly developed ELISA, using recombinant human FABP as standard [30].

Body composition. After an overnight fast, body density was measured by underwater weighing in the fasted state. Body weight was measured with a digital balance accurate to 0.01 kg (Sauter, type E1200, Albstadt-Ebingen, Germany). Lung volume was measured simultaneously with the helium dilution technique using a spirometer (Volugraph 2000, Mijnhardt). 
Table 2. Expression of UCP2 and UCP3 in Type II diabetic subjects

\begin{tabular}{|c|c|c|}
\hline & before & after \\
\hline UCP2 (amol/ug RNA) & $5.3 \pm 1.1$ & $3.4 \pm 0.9^{\mathrm{a}}$ \\
\hline UCP3L (amol/ug RNA) & $6.5 \pm 1.8$ & $2.6 \pm 1.3^{\mathrm{a}}$ \\
\hline 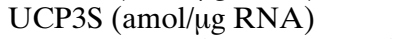 & $5.5 \pm 1.6$ & $2.1 \pm 0.6^{\mathrm{a}}$ \\
\hline UCP3 protein (arbitrary units) & $228 \pm 84$ & $136 \pm 51$ \\
\hline
\end{tabular}

${ }^{a}$ means \pm SEM. $p<0.05$ compared with before

Body fat percentage was calculated using the equations of Siri [31]. Fat-free mass (FFM) in $\mathrm{kg}$ was calculated by subtracting fat mass from total body mass.

Sample analysis. Oxygen saturation (Hemoximeter OSM2, Copenhagen, Denmark) was measured immediately after sampling in heparinized blood and was used to check arterialization. Arterialized venous blood $(15 \mathrm{ml})$ was sampled in tubes containing EDTA to prevent clotting and immediately centrifuged at $3000 \mathrm{rpm}(1000 \mathrm{~g})$ for $10 \mathrm{~min}$ at $4{ }^{\circ} \mathrm{C}$. Plasma was immediately frozen in liquid nitrogen and stored at $-80^{\circ} \mathrm{C}$ until further analysis. Plasma non-esterified fatty acids were measured using the Wako NEFA C testkit (Wako Chemicals, Neuss, Germany).

Breath samples were analysed for ${ }^{13} \mathrm{C}:{ }^{12} \mathrm{C}$ ratio using a gas chromatography-isotope ratio mass spectrometry system (GC-IRMS, Finnigan MAT 252, Bremen, Germany). For measurement of plasma palmitate enrichment, NEFA were extracted from plasma, isolated by thin-layer chromatography and reduced to their derivative methyl esters. Palmitate concentration was measured on an analytical gas chromatography with flame ionization detection using heptadecanoic acid as an internal standard and on average it comprised $23 \pm 4 \%$ of total NEFA. Isotope tracer: tracee ratio of palmitate was measured using gas chromatography-combustion-isotope ratio mass spectrometry (Finnigan MAT 252, Bremen, Germany) and corrected for the extra methyl group in its derivative.

Calculations. The ${ }^{13} \mathrm{C}$ enrichment of breath $\mathrm{CO}_{2}$ and plasma metabolites is given in tracer:tracee ratio (TTR).

Plasma fatty acid oxidation was determined from ${ }^{13} \mathrm{CO}_{2}$ enrichment in breath and ${ }^{13} \mathrm{C}$ palmitate concentration in plasma as described previously [22]. An acetate recovery factor was used to correct for loss of label in the TCA cycle [22]. Total carbohydrate and fat oxidation were calculated using stoichiometric equations [14].

Statistical analysis. Pearson correlation coefficients were calculated to assess the relation between selected variables. To compare mRNA expression and UCP content before and after weight loss, a Wilcoxon signed ranked test was done. All data are presented as means \pm SEM and a $p$ value of less than 0.05 is considered significant.

\section{Results}

Specificity of the UCP-3 antibody. Pre-incubation with the peptide yielded no detectable labelling on immunoblots with muscle homogenates, nor did the samples incubated with non-immune serum (results not shown). After incubation with the polyclonal UCP-3 antiserum a single protein band at a molecular weight of about $33000 \mathrm{M}_{\mathrm{r}}$ corresponding to UCP-3 was detected, no other protein bands between 5000 and $95000 \mathrm{M}_{\mathrm{r}}$ were found. Moreover, a T3-induced up-regulation of UCP3 was observed in human recombinant UCP3 isolated rat mitochondria (data not shown).

UCP and physiological measurements. The expression of UCP3L correlated strongly with the expression of UCP3S $(r=0.83, p<0.0005)$ (Table 2$)$.

At baseline, maximum oxygen consumption $\left(\mathrm{VO}_{2 \max }\right)$ and maximum workload $\left(\mathrm{W}_{\max }\right)$ correlated with expressions of UCP3L $(r=-0.95, p=0.004$ and $r=-0.93, \quad p=0.007$, respectively) and UCP3S mRNA expression $(r=-0.82, p=0.05$ and $r=$ $-0.91, p=0.001$, respectively). Maximum oxygen consumption $\left(\mathrm{VO}_{2 \max }\right)$ and workload $\left(\mathrm{W}_{\max }\right)$ did not, however, correlate with UCP3 protein content. At baseline, UCP mRNA expressions and protein content did not correlate with any other measured variables.

Body weight decreased after the 10 -week diet intervention from $105.5 \pm 8.2 \mathrm{~kg}$ to $91.6 \pm 7.2 \mathrm{~kg}$ $(p<0.001)$, of which $21 \%$ was accounted for by loss of FFM and $79 \%$ by loss of fat mass. Body mass index decreased from $32.9 \pm 1.3 \mathrm{~kg} / \mathrm{m}^{2}$ to $28.6 \pm 1.3 \mathrm{~kg} / \mathrm{m}^{2}$ $(p<0.001)$. Plasma NEFA concentrations decreased from $738 \pm 95$ to $502 \pm 115 \mu \mathrm{mol} / \mathrm{l}(p<0.05)$ after the 10 -week intervention. Plasma glucose $(8.4 \pm 0.6$ vs $7.8 \pm 0.8)$ and plasma insulin $(15.8 \pm 3.0$ vs $11.0 \pm 2.2)$ tended to decrease after the 10 -week diet intervention but did not reach statistical significance. Resting energy expenditure was also decreased after weight loss, from $5.7+0.4 \mathrm{~kJ} / \mathrm{min}$ to $5.0 \pm 0.3 \mathrm{~kJ} / \mathrm{min}$ $(p<0.001)$. Total fat oxidation $(248 \pm 47$ vs $156 \pm 32 \mu \mathrm{mol} / \mathrm{min}, p<0.01)$ and plasma fatty acid oxidation $(281 \pm 34$ vs $203 \pm 39 \mu \mathrm{mol} / \mathrm{min}, p=0.05)$ were also lowered by the diet intervention. Fatty acid-binding protein content of the muscle was not significantly changed after the diet intervention $(2.1 \pm 0.5$ vs $2.3 \pm 0.3 \mathrm{mg} / \mathrm{g}$ protein $)$.

The expression of UCP3L $(6.5 \pm 1.8$ vs $2.6 \pm 1.3$ $\mathrm{amol} / \mu \mathrm{g}$ total RNA) and UCP3S $(5.5 \pm 1.6$ vs $2.1 \pm 0.6 \mathrm{amol} / \mu \mathrm{g}$ total RNA) was significantly decreased after the diet intervention $(p<0.05)$ (Fig. 1). Similarly, the expression of UCP2 mRNA decreased after weight loss, from $5.3 \pm 1.1$ to $3.4 \pm 0.9 \mathrm{amol} / \mu \mathrm{g}$ total RNA (Fig. $1, p<0.05$ ). Expressions of UCP3 protein reduced by $40 \%$ on average (Table 2, $228 \pm 84$ vs $136 \pm 51, p=0.2$ ) but this did not reach statistical significance. A representative example of three subjects is given in Figure 2. Out of six subjects, two showed a small increase in UCP3 protein content. Notably, these were the two subjects with the most pronounced loss of body weight. 
A

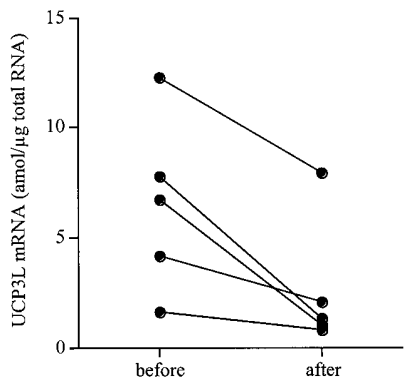

B

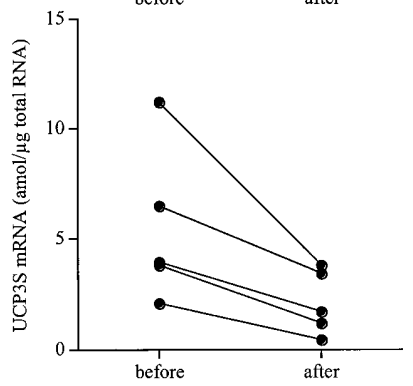

C

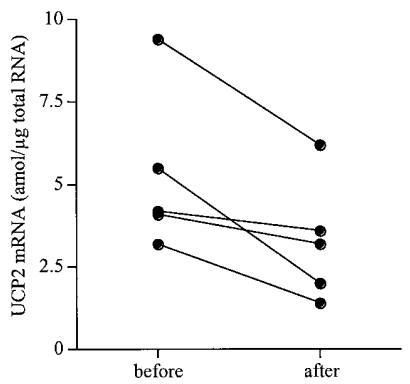

Fig. 1 A-C. The effect of a 10-week VLCD on skeletal muscle UCP3L (A), UCP3S (B) and UCP2 (C) mRNA expression

Correlations between UCP3 and diet-induced changes in the measured variables. The change in levels of UCP3L mRNA expression was negatively correlated with the changes in body weight $(r=-0.971$, $p=0.006)$, fat mass $(r=-0.9, p=0.036)$ and BMI $(r=-0.993, p=0.0007)$ but not with the change in fat free mass $(r=-0.81, p=0.1)$ or percentage body fat $(r=-0.28, p=0.64) \quad$ (Fig. 3). The change in amounts of UCP3 protein content was also negatively correlated with changes in body weight $(r=-0.83$, $p=0.043)$, fat mass $(r=-0.87, p=0.024)$, BMI $(r=-0.90, p=0.016)$ but not with the change in fat free mass $(r=-0.10, p=0.85)$ or percentage body fat $(r=-0.76, p=0.08)$ (Fig. 3).

The change in levels of UCP3L mRNA expression was positively correlated with changes in variables of fatty acid metabolism, i.e. resting RQ $(r=0.88, \quad p=0.05)$, plasma fatty acid oxidation $(r=0.922, p=0.0261)$ and FABP content in skeletal muscle $(r=0.928, p=0.023)$ (Fig. 4). Also, the change in amounts of UCP3 protein content was positively correlated with FABP content $(r=0.84$, $p=0.039$ ) (Fig.4). No correlations between either the change in UCP3S or UCP2 expressions and any of the measured variables mentioned above were found.
As mentioned above, energy expenditure was significantly reduced after weight loss. The diet-induced changes in UCP3 protein content did not, however, correlate with the changes in resting energy expenditure, both without $(r=0.11, p=0.84)$ or with $(r=0.09, p=0.86)$ adjustment for changes in FFM and fat mass. Notably, the diet-induced changes in UCP3 protein contents did not correlate with changes in plasma NEFA concentrations $(r=0.03$, $p=0.96)$.

\section{Discussion}

The recently discovered human uncoupling proteins UCP2 and UCP3 have been suggested to be involved in energy metabolism and obesity $[32,33]$. The finding that UCP2 and UCP3 mRNA are up-regulated by NEFA and fasting has led to the hypothesis that these UCPs could also be involved in the metabolism of fatty acids. The results from our study suggest that the capacity to maintain high UCP3 mRNA expression and, more important UCP3 protein content during weight loss could be a determinant which promotes further weight loss, possibly through a role for UCP3 in the metabolism of fatty acids in skeletal muscle.

So far, most of the data reported on the role of UCP3 in human energy and substrate metabolism is based on measurements of UCP3 mRNA expressions due to lack of specific UCP3 antibodies. Here we present an antibody that successfully passed all specifity checks and detects a single protein band at about $33000 \mathrm{M}_{\mathrm{r}}$ corresponding to UCP3. No other protein bands were detected and pre-incubation with the peptide yielded no detectable labelling. We therefore believe that the present antibody can be used to detect UCP3 protein contents in human skeletal muscle.

The effect of weight reduction on UCP2 and UCP3 mRNA expression has been studied before in obese subjects. After 4 weeks of a very low calorie diet (VLCD) obese women lost on average $7 \%$ of their initial body weight but this weight loss had no effect on UCP2 mRNA expression in their adipose tissue [7]. Studies of the effect of a 10-20\% weight reduction on UCP2 mRNA expression in adipose tissue and skeletal muscle, as well as on skeletal muscle UCP3 mRNA expression found that UCP3 mRNA expression was decreased by $30-50 \%$ after weight reduction but UCP2 mRNA expression was increased by $30 \%$ in skeletal muscle and $60 \%$ in adipose tissue [20]. Finally, it has been reported that UCP3 mRNA expression in skeletal muscle was reduced after weight loss due to gastric banding surgery [21]. None of these studies measured any physiological variables which could be linked to the change in UCP mRNA expression or UCP protein content. In our study, we found that in a period of weight stability after a 10- 


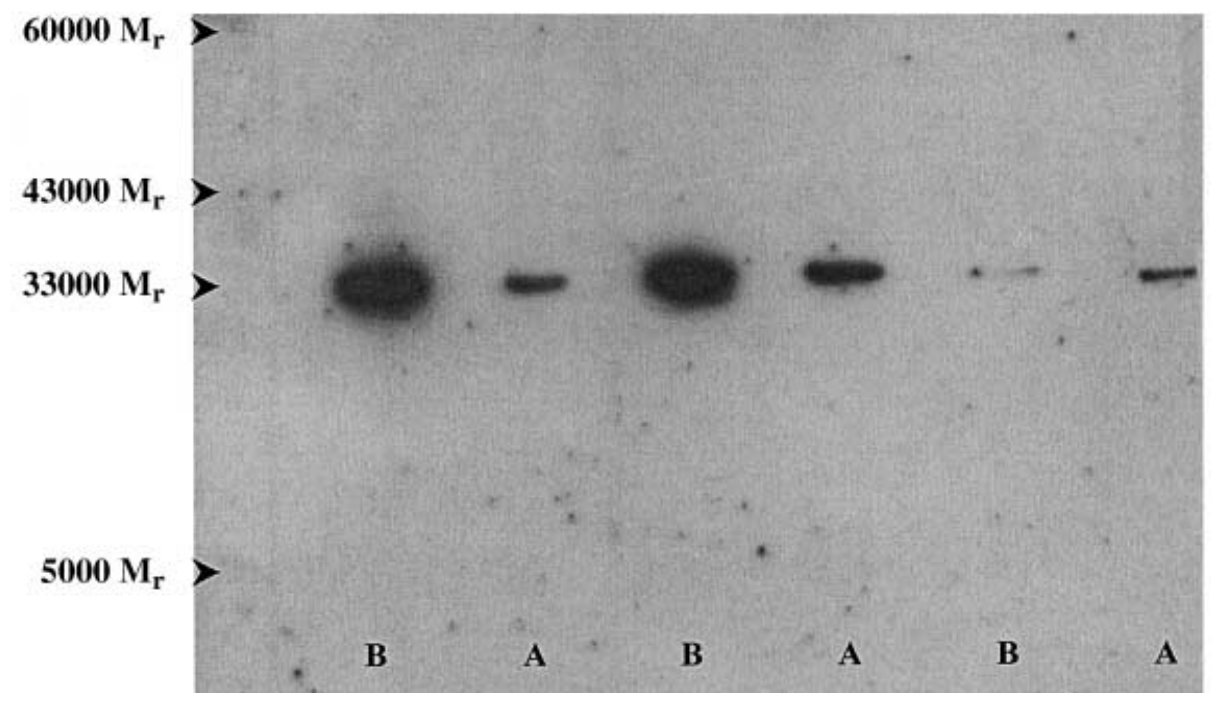

Fig. 2. Representive example of UCP3 on western blot. Lanes 1,3 and 5 represent three subjects before VLCD, lanes 2, 4 and 6 represent the same subjects after VLCD

week diet intervention resulting in a body weight change of on average about $15 \mathrm{~kg}$, both the expression of UCP2 and UCP3 mRNA in skeletal muscle of Type II diabetic subjects was decreased. The decrease in UCP3 protein content ( $40 \%$ on average) did not, however, reach statistical significance because two out of six subjects showed a slight increase in $\mathrm{UCP} 3$ protein content. We measured UCP2 and UCP3 expression after a period of weight loss followed by 2 weeks of stable weight. Therefore, our data is not in contrast with the increased UCP3 content observed during fasting but might show a defensive mechanism designed to maintain body weight. Notably, the change in UCP3 mRNA expression and UCP3 protein content during weight loss was negatively correlated with the change in body mass index. Thus, the subject with the most pronounced weight loss showed even a small increase in UCP3 protein content, whereas the subjects with a large decrease in UCP3 protein content had only minor weight loss. These results suggest that the capacity to maintain high levels of UCP3 protein content might be a determining factor in diet-induced weight loss.

We have shown previously, that UCP3 mRNA expression is a determinant of energy metabolism in Pima Indians [6]. Skeletal muscle UCP3 mRNA expression was positively correlated with sleeping metabolic rate. Furthermore, linkage and polymorphism studies have shown a role for UCPs in energy metabolism $[4,5]$. A decreased expression of UCPs after weight loss could thus account for the observed decrease in energy expenditure after weight loss [34, $35]$. In our present study, the change in skeletal muscle UCP2 and UCP3 mRNA expression and UCP3 protein content did, however, not correlate with the change in resting energy expenditure. Furthermore, the subject with most weight loss showed the most pronounced decrease in energy expenditure (as would be expected) and smallest change in UCP expression.

Apart from an effect on energy metabolism, weight loss also results in a decrease in fat oxidation. Because Type II diabetes is characterized by a diminished plasma fatty acid uptake and oxidation by the skeletal muscle $[17,18]$, we measured both total and plasma fatty acid oxidation before and after weight loss. We found that the change in UCP3 mRNA expression with weight loss correlated positively with the change in plasma fatty acid oxidation. Thus, the subjects with the most pronounced decrease in UCP3 mRNA expression also showed the most pronounced decrease in plasma fatty acid oxidation (which can be considered as a factor limiting weight loss). Notably, the change in UCP3 protein content was also correlated with the change in skeletal muscle cytosolic-FABP content. It has been shown previously that the uptake and oxidation of fatty acid by skeletal muscle is related to the cytosolic FABP content [36]. Moreover, for the heart it was shown that FABP is involved in the uptake and oxidation of fatty acids [37]. Therefore, these findings suggest that maintaining UCP3 protein content after weight loss could promote further weight loss by facilitating plasma fatty acid oxidation and confirm the recent findings of a role for UCPs in the oxidation of fatty acids. Thus an exon 6-splice polymorphism which probably results in lowered UCP3 mRNA expression, was strongly associated with a decreased fat oxidation capacity [38]. Furthermore, it was recently shown that inhibition of mitochondrial fatty acid oxidation decreased the expression of UCP3 in the rat $\mathrm{m}$. tibialis anterior, whereas plasma fatty acids, which are suggested to regulate UCPs, were increased [39]. Finally, it has been suggested that UCPs can exert their un- 


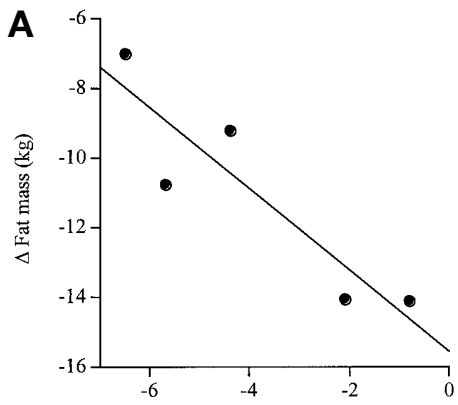

$\triangle$ UCP3L mRNA (amol/ $\mu \mathrm{g}$ RNA)
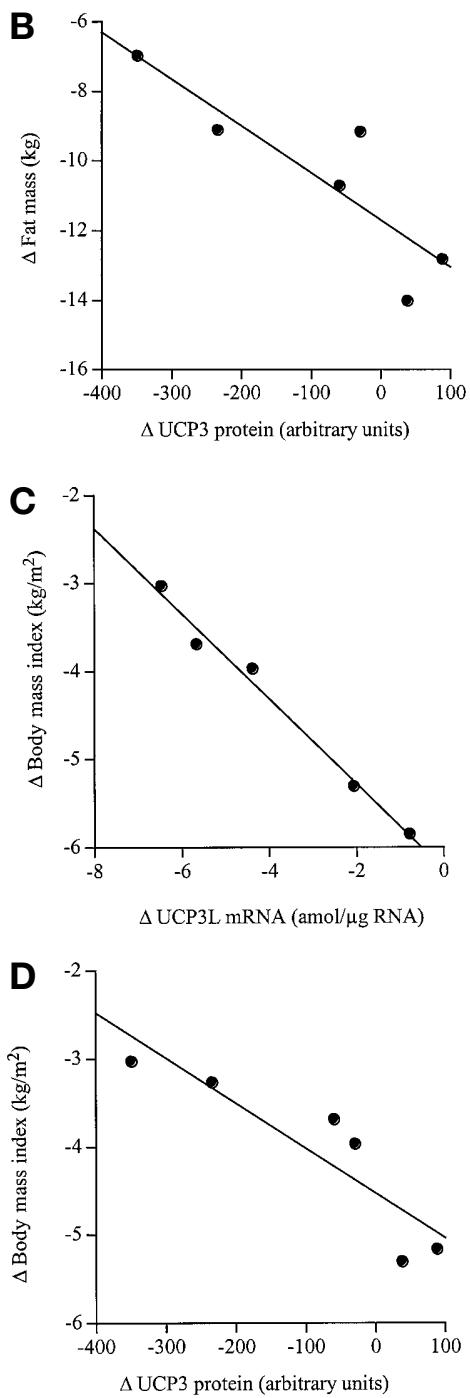

Fig. 3 A-D. Relation between the VLCD-induced changes in fat mass and the expression of UCP3L mRNA $(\mathbf{A}, r=-0.90$, $p=0.0 .036)$ and UCP3 protein content (B, $r=-0.87$, $p=0.024)$, and changes in body mass index and the expression of UCP3L mRNA $(\mathbf{C}, r=-0.99, p=0.0 .0007)$ and UCP3 protein content $(\mathbf{D}, r=-0.90, p=0.016)$
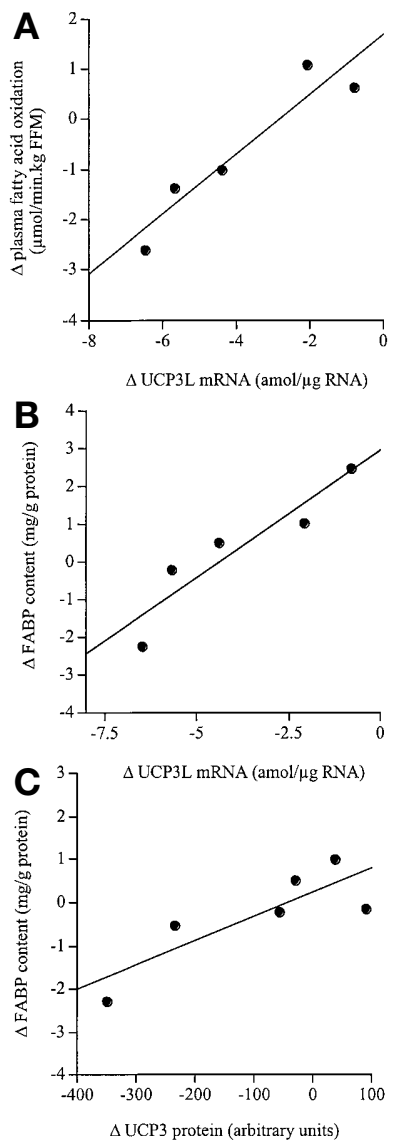

Fig. 4A-C. Relation between the VLCD-induced changes in the expression of UCP3L mRNA and plasma fatty acid oxidation $(\mathbf{A}, r=0.92, p=0.026)$ and skeletal muscle FABP content $(\mathbf{B}, r=0.93, p=0.023)$, and changes in the UCP3 protein content and skeletal muscle FABP content $(\mathbf{C}, r=0.84, p=0.039)$

coupling effect by being involved in fatty acid cycling across the inner mitochondrial matrix [40]. On the matrix side of the mitochondrial membrane, UCPs could be involved in the translocation of the fatty acid anions to the cytosolic side of the membrane. Here the fatty acid anion is protonated and "flipflops" rapidly back to the matrix side because neutral fatty acids can easily "flip-flop" across the membrane. In this way, the proton gradient is lowered and heat is produced. Accordingly, these findings, together with our finding that UCP3 mRNA expression was correlated with plasma fatty acid oxidation and, more importantly, UCP3 protein content was correlated with cytosolic FABP content suggest a role for UCPs in transporting intracellular fatty acids across the mitochondrial membrane, permitting the oxidation of fatty acids. It is therefore also possible that altered UCP3 protein content plays a part in the diminished fatty acid uptake and oxidation capacity in Type II diabetes $[17,18]$ because, although contradictory, it is possible that Type II diabetic subjects have altered UCP3 mRNA expression [19, 41]. 
Diet-induced weight loss reduced the mRNA expression of all UCPs in skeletal muscle of Type II diabetic subjects in our study. Notably, the change in UCP3 protein content was negatively correlated with the change in body mass index, suggesting that the ability to maintain high UCP3 protein contents on a VLCD could facilitate weight loss by maintaining plasma fatty acid oxidation. The decreased expression of UCPs after the weight loss period was not correlated with a decreased rate of energy expenditure, but the change in UCP3 expression was correlated with the change in plasma fatty acid oxidation, as well as with the change in skeletal muscle FABP content. Therefore, these data suggest a role for UCP3 protein in the handling of fatty acids as a fuel.

Acknowledgements. Dr. Schrauwen is supported by a grant from the Netherlands Organisation for Scientific Research (NWO). We thank Eli Lilly and Company for providing us with the UCP3 antibody. P. Vallie is kindly thanked for the help in mRNA analysis. The laboratories (1 and 5) are members of the Concerted Action FATLINK (FAIR-CT98-4141) supported by the European Commission. This work was supported by a grant from the Dutch Diabetes Foundation.

\section{References}

1. Ricquier D, Casteilla L, Bouillaud F (1991) Molecular studies of the uncoupling protein. FASEB J 5: 2237-2242

2. Boss O, Samec S, Paoloni-Giacobino A et al. (1997) Uncoupling protein-3: a new member of the mitochondrial carrier family with tissue-specific expression. FEBS Lett 408: $39-42$

3. Vidal-Puig A, Solanes G, Grujic D, Flier JS, Lowell BB (1997) UCP3: An uncoupling protein homologue expressed preferentially and abundantly in skeletal muscle and brown adipose tissue. Biochem Biophys Res Commun 235: 79-82

4. Bouchard C, Pérusse L, Chagnon YC, Warden G, Ricquier D (1997) Linkage between markers in the vicinity of the uncoupling protein 2 gene and resting metabolic rate in humans. Hum Mol Genet 6: 1887-1889

5. Walder K, Norman RA, Hanson RL et al. (1998) Association between uncoupling protein polymorphisms (UCP2UCP3) and energy metabolism/obesity in Pima Indians. Hum Mol Genet 7: 1431-1435

6. Schrauwen P, Xia J, Bogardus C, Pratley R, Ravussin E (1999) Skeletal muscle UCP3 expression is a determinant of energy expenditure in Pima Indians. Diabetes 48: 146-149

7. Barbe P, Millet L, Larrouy D et al. (1998) Uncoupling protein-2 messenger ribonucleic acid expression during verylow-calorie diet in obese premenopausal women. J Clin Endocrinol Metab 83: 2450-2453

8. Boss O, Samec S, Dulloo A et al. (1997) Tissue-dependent upregulation of rat uncoupling protein-2 expression in response to fasting or cold. FEBS Lett 412: 111-114

9. Samec S, Seydoux J, Dulloo AG (1998) Interorgan signaling between adipose tissue metabolism and skeletal muscle uncoupling protein homologs: is there a role for circulating free fatty acids? Diabetes 47: 1693-1698

10. Boss O, Samec S, Kühne F et al. (1998) Uncoupling protein-3 expression in rodent skeletal muscle is modulated by food intake but not by changes in environmental temperature. J Biol Chem 273: 5-8

11. Gong D-W, He Y, Karas M, Reitman M (1997) Uncoupling protein-3 is a mediator of thermogenesis regulated by thyroid hormone, B3-adrenergic agonists, and leptin. J Biol Chem 272: 24129-24132

12. Millet L, Vidal H, Andreelli F et al. (1997) Increased uncoupling protein-2 and -3 mRNA expression during fasting in obese and lean humans. J Clin Invest 100: 2665-2670

13. Boss O, Bobbioni-Harsch E, Assimacopoulos-Jeannet F et al. (1998) Uncoupling protein-3 expression in skeletal muscle and free fatty acids in obesity. Lancet 351: 1933

14. Weigle DS, Selfridge LE, Schwartz MW et al. (1998) Elevated free fatty acids induce uncoupling protein 3 expression in muscle. A potential explanation for the effect of fasting. Diabetes 47: 298-302

15. Khalfallah Y, Fages S, Laville M, Langin D, Vidal H (2000) Regulation of uncoupling protein-2 and uncoupling protein-3 mRNA expression during lipid infusion in human skeletal muscle and subcutaneous adipose tissue. Diabetes 49: $25-31$

16. Samec S, Seydoux J, Dulloo AG (1999) Post-Starvation gene expression of skeletal muscle uncoupling protein 2 and uncoupling protein 3 in response to dietary fat levels and fatty acid composition. A link with insulin resistance. Diabetes 48: 436-441

17. Kelley DE, Simoneau J-A (1994) Impaired free fatty acid utilization by skeletal muscle in non-insulin dependent diabetes mellitus. J Clin Invest 94: 2349-2356

18. Blaak EE, Wagenmakers AJ, Glatz JF et al. (1998) Plasma free fatty acid utilization and fatty acid binding protein content are diminished in forearm skeletal muscle of Type II diabetic subjects during overnight fasted conditions and during exercise. Diabetologia 41: 811 (Abstract)

19. Vidal H, Langin D, Andreelli F et al. (1999) Lack of skeletal muscle uncoupling protein 2 and 3 mRNA induction during fasting in type-2 diabetic subjects. Am J Physiol 277: E830-E837

20. Vidal-Puig A, Rosenbaum M, Considine RC et al. (1999) Effects of obesity and stable weight reduction on UCP2 and UCP3 gene expression in humans. Obes Res 7: 133-140

21. Esterbauer H, Oberkofler H, Dallinger G et al. (1999) Uncoupling protein-3 gene expression: reduced skeletal muscle mRNA in obese humans during pronounced weight loss. Diabetologia 42: 302-309

22. Schrauwen P, van Aggel-Leijssen DP, van Marken Lichtenbelt WD et al. (1998) Validation of the $\left[1,2-{ }^{13} \mathrm{C}\right]$-acetate recovery factor for correction of $\left[\mathrm{U}-{ }^{13} \mathrm{C}\right]$-palmitate oxidation rates in humans. J Physiol (Lond) 513: 215-223

23. Sidossis LS, Coggan AR, Gastaldelli A, Wolfe RR (1995) A new correction factor for use in tracer estimations of plasma fatty acid oxidation. Am J Physiol 269: E649E656

24. Schrauwen P, Wagenmakers AJ, van Marken Lichtenbelt WD, Saris WH, Westerterp KR (2000) Increase in fat oxidation on a high-fat diet is accompanied by an increase in triglyceride-derived fatty acid oxidation. Diabetes 49: 640-646

25. Bergstrom J, Hermansen L, Hultman E, Saltin B (1967) Diet, muscle glycogen and physical performance. Acta Physiol Scand 71: 140-150

26. Chomozynski P, Sacchi N (1987) Single-step method of RNA isolation by acid guanidinium thiocyanate-phenolchloroform extraction. Anal Biochem 162: 156-159

27. Millet L, Vidal H, Larrouy D et al. (1998) mRNA expression of the long and short forms of uncoupling protein-3 in obese and lean humans. Diabetologia 41: 829-832 
28. Laemmli UK (1970) Cleavage of structural proteins during the assembly of the head of bacteriophage T4. Nature 227: 680-685

29. Towbin H, Staehelin T, Gordon J (1979) Electrophoretic transfer of proteins from polyacrylamide gels to nitrocellulose sheets: procedure and some applications. Proc Natl Acad Sci U S A 76: 4350-4354

30. Wodzig KW, Pelsers MM, van der Vusse GJ, Roos W, Glatz JF (1997) One-step enzyme-linked immunosorbent assay (ELISA) for plasma fatty acid-binding protein. Ann Clin Biochem 34: 263-268

31. Siri WE (1956) The gross composition of the body. Adv Biol Med Phys 4: 239-280

32. Schrauwen P, Walder K, Ravussin E (1999) Human uncoupling proteins and obesity. Obes Res 7: 97-105

33. Boss O, Muzzin P, Giacobino J-P (1998) The uncoupling proteins, a review. Eur J Endocrinol 139: 1-9

34. Weigle DS, Sande KJ, Iverius PH, Monsen ER, Brunzell JD (1988) Weight loss leads to a marked decrease in nonresting energy expenditure in ambulatory human subjects. Metabolism 37: 930-936

35. Leibel RL, Rosenbaum M, Hirsch J (1995) Changes in energy expenditure resulting from altered body weight. N Engl J Med 332: 621-628
36. Veerkamp JH, van Moerkerk HT (1993) Fatty acid-binding protein and its relation to fatty acid oxidation. Mol Cell Biochem 123: 101-106

37. Schaap FG, Binas B, Danneberg H, van der Vusse GJ, Glatz JF (1999) Impaired long-chain fatty acid utilization by cardiac myocytes isolated from mice lacking the hearttype fatty acid binding protein gene. Circ Res 85: 329-337

38. Argyropoulos G, Brown AM, Willi SM et al. (1998) Effects of mutations in the human uncoupling protein 3 gene on the respiratory quotient and fat oxidation in severe obesity and type 2 diabetes. J Clin Invest 102: 1345-1351

39. Samec S, Seydoux J, Dulloo AG (1999) Skeletal muscle $\mathrm{UCP} 3$ and UCP2 gene expression in response to inhibition of free fatty acid flux through mitochondrial beta-oxidation. Pflugers Arch 438: 452-457

40. Garlid KD, Orosz DE, Modriansky M, Vassanelli S, Jezek $\mathrm{P}$ (1996) On the mechanism of fatty acid-induced proton transport by mitochondrial uncoupling protein. J Biol Chem 271: 2615-2620

41. Krook A, Digby J, OqRahilly S, Zierath JR, WallbergHenriksson H (1998) Uncoupling protein 3 is reduced in skeletal muscle of NIDDM patients. Diabetes 47: $1528-1531$ 